\title{
Revelations of the World: Transnationalism and the Politics of Perception in Papua New Guinea
}

James Slotta

ABSTRACT Like many over the past century, people in the Yopno Valley of Papua New Guinea have experienced a burgeoning of connections with people across great geographical distances. Building on Benedict Anderson's well-known discussion of the nation as a "community" imagined in part through the realist framing of newspaper reporting, novels, censuses, and so on, I argue that revelation is an interactional frame central to an emerging global imaginary in the Yopno Valley, one that lies at the heart of Yopno engagements with transnational projects ranging from Christian missionization to environmental conservation and development through Western-style education. In the course of sermons, community meetings, public announcements, and the like, people frequently reveal knowledge of transnational institutions to others, presenting themselves as the necessary mediators between an "out-of-touch" community and a knowledgeable, powerful, and yet obscure world of transnational actors. The world perceived through revelation is one in which persons are defined by their place in a global hierarchy organized by the trajectory of knowledge in circulation, with the Yopno, the last to know, at the bottom. This imaginary, in turn, is reshaping power relations in Yopno communities and influencing people's understanding of and interest in various transnational projects. [transnationalism, frame, social imaginary, interaction, Papua New Guinea, Melanesia]

RESUMEN Como muchos otros, la gente en el Valle Yopno de Papúa Nueva Guinea ha vivido la experiencia, durante el siglo pasado del florecimiento de conexiones con gente a través de grandes distancias geográficas. Basado en la bien conocida discusión de Benedict Anderson sobre la nación como una "comunidad" imaginada en parte a través de una marco realista de cobertura de prensa, novelas, censos, y demás argumento que la revelación es un marco interactual central para el imaginario global emergente en el Valle Yopno, uno que se sitúa en el corazón de las interacciones con proyectos transnacionales que van desde la misionización cristiana hasta la conservación ambiental y el desarrollo a través de la educación al estilo occidental. En el curso de los sermones, reuniones comunales, anuncios públicos, y demás, la gente frecuentemente revela conocimiento de las instituciones transnacionales a otros, presentándose así mismos como los mediadores necesitados entre una comunidad desfasada y un mundo experto poderoso y sin embargo, oscuro de actores transnacionales. El mundo percibido a través de la revelación es uno en el cual las personas son definidas por su lugar en una jerarquía global organizada por la trayectoria del conocimiento en circulación con el Yopno, el último en saber, en la parte inferior. Este imaginario, a la vez, esta reestructurando la relaciones de poder en comunidades Yopno e influenciando el entendimiento de la gente de, y el interés en varios proyectos transnacionales. [transnacionalismo, marco, imaginario social, interacción, Papúa Nueva Guinea, Melanesia] 
$\mathrm{I}$ n 2009, preparations were ramping up for a major event celebrating the establishment of a national conservation area in the Yopno, Uruwa, and Som valleys of Papua New Guinea. The Yopno-Uruwa-Som (YUS) Conservation Area, the first of its kind in Papua New Guinea, had been legally ratified by the government in January 2009. A number of national and provincial leaders, including the prime minister, were expected to attend the celebration, which was being hosted by four communities in the Yopno Valley. People there were anticipating an event like none seen before in this remote region - a region that requires a two-day hike through the Finisterre Mountains to reach the nearest roads and boats that provide access to markets, schools, and jobs in the cities of Lae and Madang (see Figure 1). For months, they had been preparing housing, collecting garden produce, securing pigs, and gathering firewood for the influx of visitors expected from other villages in the region, as well as politicians, conservation NGO representatives, and the press.

The conservation area itself is comprised of land owned by lineages and clans in the Yopno, Uruwa, and Som valleys, home to roughly 11 thousand people whose livelihood consists largely of food and resources, including game, harvested from their land. Six or so languages are spoken in the three valleys - the number varies depending on who is counting and for what purpose - and these languages serve as a basis for distinguishing one ethnolinguistic group from another.

Though the conservation area and the celebration were on everybody's lips for weeks leading up to the celebration, the chatter was not all excitement and anticipation. The conservation area included roughly three hundred square miles of land pledged by landowners in the Yopno and neighboring valleys, land that could no longer be used for hunting and harvesting materials. For people who find food, housing materials, and firewood in the forests surrounding their villages and, importantly, whose land is central to their sense of personhood, these pledges were not made lightly. As the celebration drew near, the conservation area and the U.S.based NGO that had conceived and championed it became a focus of community discussions.

Many Yopno were uncertain about what would come of pledging their land to the conservation area. Would they receive money in exchange for their pledges of land? Would the conservation NGO keep poachers off their land if it became part of the conservation area? How could they use the land that they pledged? In addition, why was this U.S.based NGO so interested in their land? Despite the efforts of the conservation NGO to explain what they were doing and why, the questions persisted.

I also spent a fair amount of time being quizzed about the conservation NGO, doing my best to respond to people's questions with what I knew of the conservation project. However, seeing that my answers continually failed to satisfy people, I realized that many were not looking for clarification of what the NGO was saying. Instead, they were looking for insight into what was left unsaid - for the revelation of some hidden reality that lay behind the conservation efforts. In other regions of Papua New Guinea, people believe that Christian missionaries "deliberately 'hide' from them the knowledge they require in order to understand Christianity and get it to work for them" (Kulick 1992:161). Here in the Yopno Valley, there were concerns that the NGO was hiding what they were really up to and that there was more to their efforts than merely protecting an endangered species of tree kangaroo. Thus, the questions persisted.

I came to see the questions about the conservation area as another instance of people seeking me out as a source capable of revealing hidden realities. This was a role I was asked to fill on subjects ranging from the true meaning of English words, which some felt their Papua New Guinean teachers either did not know or were hiding from them, to the truth about a family's own myths and genealogies. Many hoped that my computer, in particular, would be able to provide them the true version of their own myths and genealogies, which would establish their rights to parcels of land and offer information necessary for interacting with powerful spirits. Even as I was sought out as a source of revelation on occasion, I was also a subject in need of revelation. On numerous occasions, I was told of the questions and explanations circulating in the valley about what I was really doing there.

These experiences and my research on Yopno political communication converged on the same point: the importance of revelation as a communicative practice through which social life is experienced and conceptualized. ${ }^{1}$ It is generally accepted that there is a deeper, hidden reality lurking below the surface of phenomena, even those that seem to be most mundane. This hidden reality is accessible through the revelations of more knowledgeable others. Revelations present a truer, esoteric representation of reality, explicitly or implicitly distinguishing it from a less true, exoteric one. In this respect, revelation frames reality as something that is obscure and subject to multiple representations, some of which are more correct than others.

As a form of communicative practice, revelation also involves a disparity of knowledge among interactional participants - speaker(s) and addressee(s). In events of revelation, speakers' esoteric understandings of reality are set in contrast to their addressees' exoteric perspectives. At the same time, speakers make their esoteric perspectives available to their addressees, putting knowledge into circulation. Revelation not only frames reality as obscure, but as an interactional frame, it locates participants with respect to one another as persons with differential knowledge of and access to an obscure reality. In other words, a revelatory frame encompasses both the context of communication (e.g., the roles, identities, and relations of interactional participants) and the content of what is communicated (see Goffman 1974 , 1979, for a more extensive discussion of frames). 


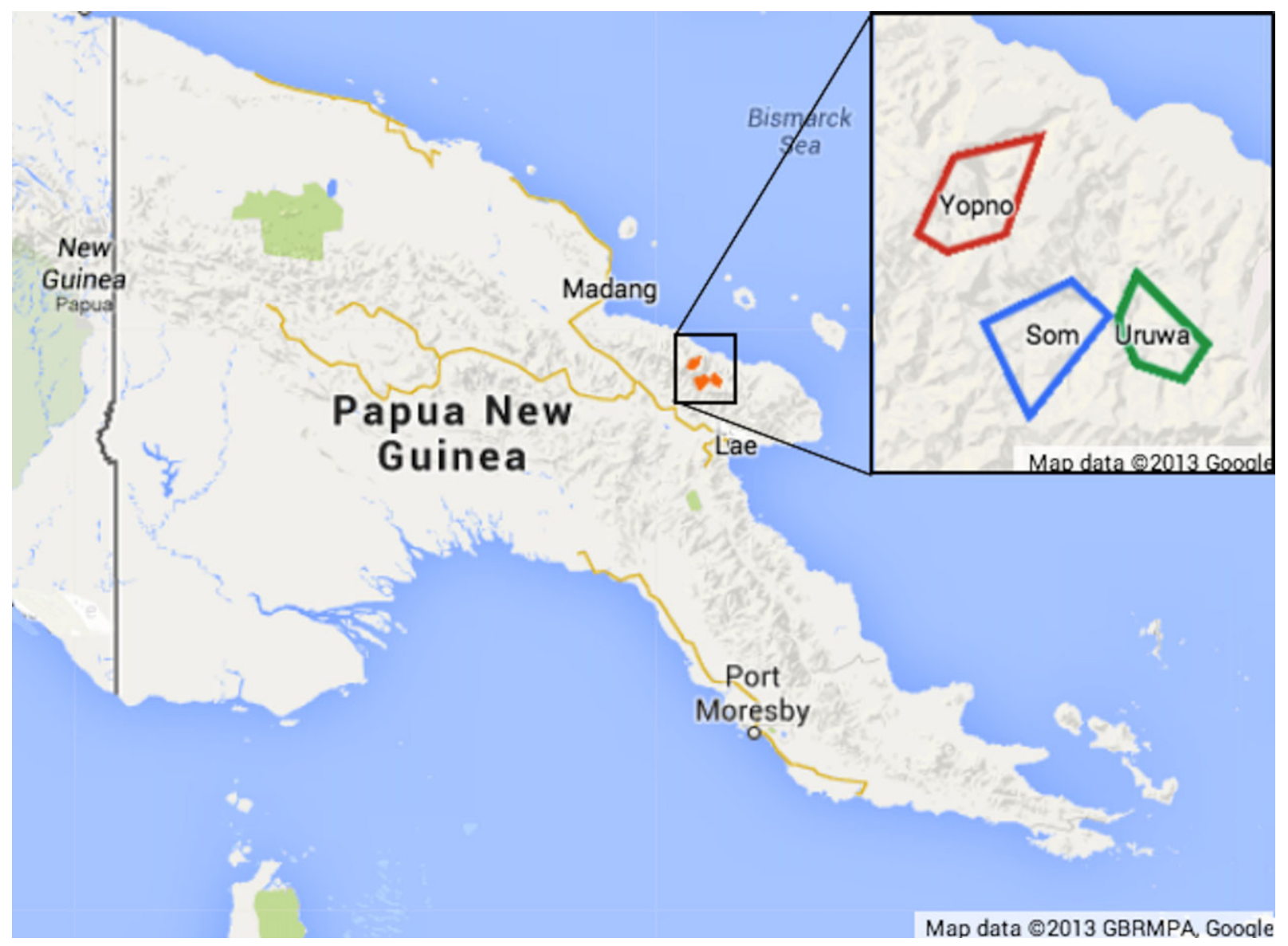

FIGURE 1. The Yopno, Som, and Uruwa valleys in Papua New Guinea.

In this article, I argue that revelation as an interactional frame lies at the heart of Yopno engagements with transnational projects ranging from Christian missionization to environmental conservation and development through Western-style education. The colonial and postcolonial eras in Papua New Guinea, as in many other places, involved a burgeoning of connections between people across great geographical and sociopolitical distances. Alongside these increased connections, various "social imaginaries" (Taylor 2004) have emerged, providing different ways of conceptualizing social and political relations between people who live at a great distance from one another. As socially unrelated people who are largely unknown to each other may come to see themselves as common members of a nation imagined as a community (Anderson 1991), "global imaginaries" (Steger 2008) have begun to play an important role in shaping transnational relations.

Building on Benedict Anderson's well-known discussion of the nation as a community imagined through particular interactional frames (e.g., the "sociological realism" found in novels, newspapers, censuses, and the like), I discuss revelation as an interactional frame central to one emerging imaginary of the global that is prominent in the Yopno Valley. Rather than attend to the content that "flows" through transnational communicative circuits, I focus on revelation as a frame that has come to mediate those flows and serve as a medium for conceptualizing transnational sociopolitical relations.

Far from being a fruitless fantasy, this revelatory mediation of "the global" has had significant effects on Yopno engagements with transnational actors and institutions. Churches and schools, in particular, are seen as sources of foreign, esoteric knowledge that confer status and power on those who can gain access to it. Many hope that their children or grandchildren will leave behind their land and horticultural practices to become "knowledge workers" in the cities of Papua New Guinea and beyond. As a result, much community effort is now directed toward building and supporting schools and churches as institutional sites where knowledge coming from outside the valley is revealed (see Figures 2 and 3).

The revelatory mediation of "the global" has also transformed politicking in Yopno communities, disrupting power relations between old and young, men and women. Now, younger people assume a greater measure of authority through their revelations about the world of NGOs, governments, and Christianity, which are based on knowledge that they have acquired from schools, the mass media, and sojourns in urban areas of Papua New Guinea. In a place where power derives in part from having esoteric knowledge 


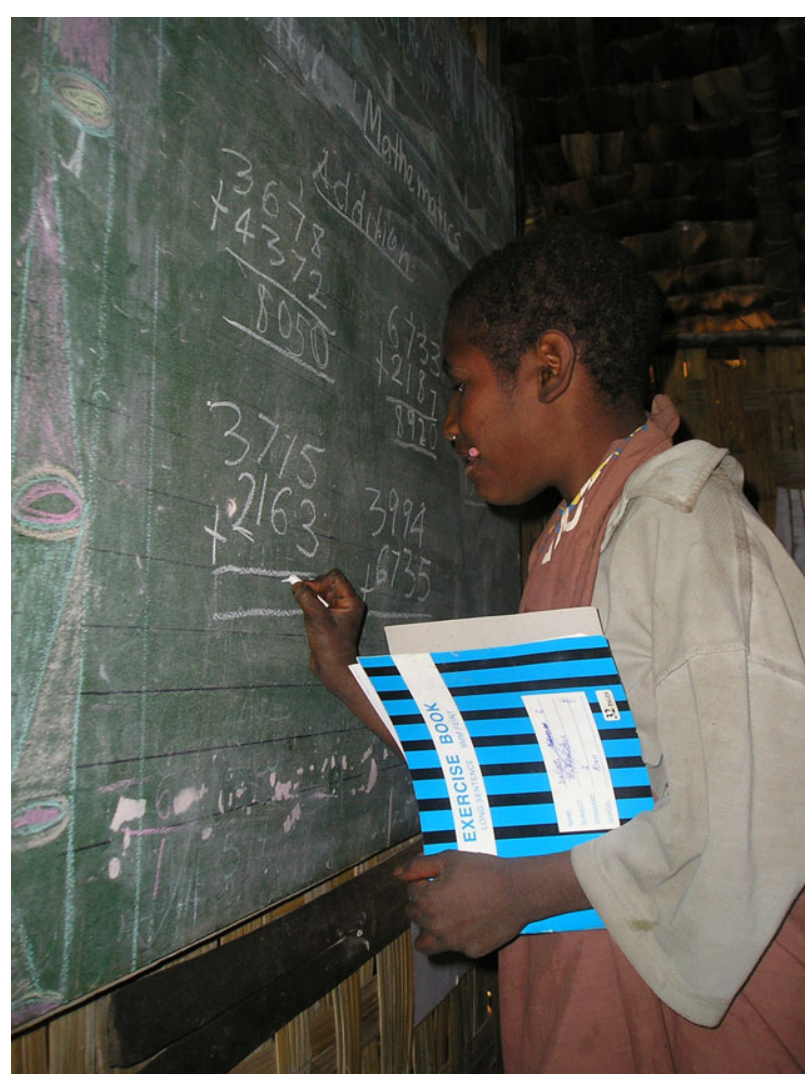

FIGURE 2. A "preschool" student does arithmetic on the chalkboard.

and selectively revealing it to others, access to knowledge of (trans)national social spheres has empowered younger men and women to take on leadership roles as teachers, politicians, community leaders, and, more generally, advisers to their elders. In short, the revelatory mediation of the transnational is reshaping social and political relations in the Yopno Valley. At the same time, the importance of revelation in community politics is shaping people's conceptualizations of "the global" and their place in it. ${ }^{2}$

\section{INTERACTIONAL FRAME, MEDIATION, AND SOCIAL IMAGINARY}

Anderson's (1991) Imagined Communities provides perhaps the best-known discussion of the linguistic mediation of a large-scale social imaginary. For Anderson, novels, newspaper articles, censuses, and other linguistic materials that bear features of what we might term "sociological realism" play an important role in giving rise to an imagination of the nation as a community. In such textual materials, the social world depicted (e.g., characters, settings) appears continuous with the social world of the author and readers, a hallmark of sociological realism. In Anderson's words, "the casual progression [in the opening lines of José Rizal's novel Noli Me Tangere] . . . from the 'interior' time of the novel to the 'exterior' time of the [Manila] reader's everyday life gives a hypnotic confirmation of the solidity of a single community, embracing characters, author and readers, moving onward through calendrical time" (1991:27). The charac- ters and settings portrayed in the fictional world of a realist novel mirror those found in the world of author and readers alike. Along with newspaper articles, censuses, and many other genres where this frame is commonly encountered, the realist novel fosters a sense that there is a common social world - a community - encompassing authors, readers, and the figures represented in these texts. Sociological realism is, then, an interactional frame, one that conjures an imagined community, incorporating not only the characters depicted in novels and the like but interactional participants (e.g., author, reader) as well.

Anderson offers a powerful model of how a particular interactional frame realized in communicative practices provides a basis for imagining a large-scale collectivity and, thus, how it plays a role in bringing a new type of sociopolitical formation into being. It is important to recognize that Anderson's analysis does not focus merely on how language is used to represent a situation, real or fictional. He attends to the context in which representations are communicated, looking at how sociological realism as an interactional framework configures the relationship of interactional participants to each other and to the world represented in realist novels and the like. His approach tacks back and forth between linguistic representations and their interactional context, a mode of analyzing language use developed in more detail by a number of scholars who have explored how the use of speech as a means of representing the world relates to the use of speech as a means of interacting with others in the world (e.g., the sociological literary studies of Bakhtin [1981], Goffman's [1979] discussion of "footing," and Silverstein's [1997] "interactional text"). ${ }^{3}$ I draw on these approaches here to highlight the role of revelation as an interactional frame that is giving shape to an imaginary of the global in the Yopno Valley. Encompassing both interactional context and linguistic representations, interactional frames provide analytic purchase not only on how people represent the nation or the global but also on how they locate themselves and others within large-scale social imaginaries in communicative events.

Though approaches similar to Anderson's have been developed in discussions not only of nationalism but also of the public sphere (e.g., Warner 1990) and modernity (e.g., Keane 2007; Robbins 2001), the study of transnationalism has attended much less to the interactional frames, especially frameworks of communicative action, that mediate such imaginaries. This is perhaps due to the contemporary dominance of a neoliberal, market-centered imaginary in Western policy circles and the media (Steger 2008), where economic transactions, not communicative actions, provide a basis for imagining transnational relations.

Of course, communication is central to most discussions of globalization, in which the speed or volume of information, ideas, ideologies, images, symbols, languages, discourses, and even interactional frameworks themselves (e.g., Schieffelin 1995) "flowing" through transnational communications networks mark the present era of globalization 


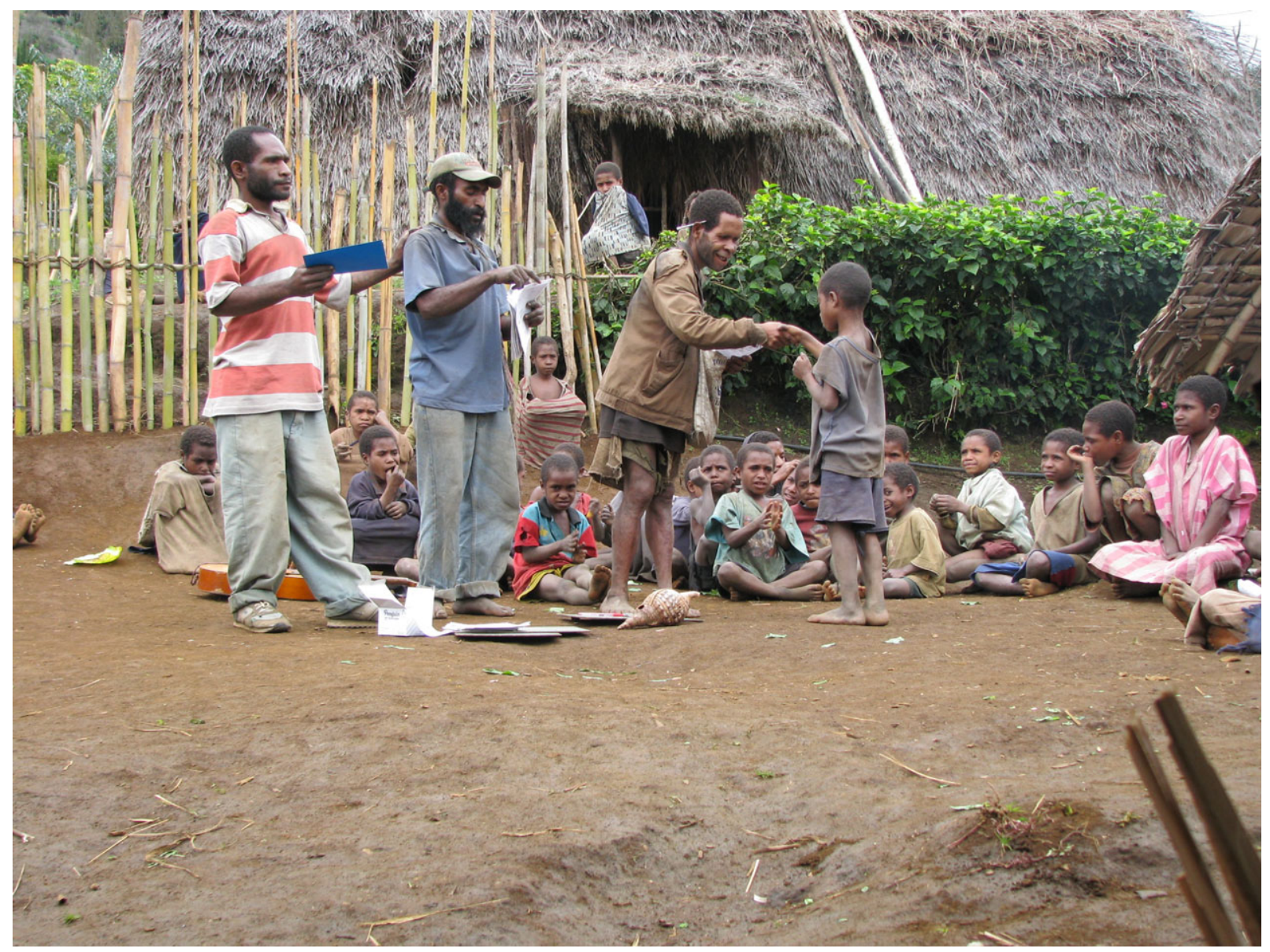

FIGURE 3. A "preschool" student receives test results and a handshake from a community leader.

as quantitatively, if not qualitatively, distinct from globalization in earlier historical periods. One great virtue of the anthropology of globalization is its insistence that analysts attend not only to transnational flows but also to the way such flows are channeled (Tsing 2000), translated (Gal 2003), customized (Inda and Rosaldo 2008), or otherwise mediated (Mazzarella 2004) in particular institutional sites and in socioculturally specific ways.

In that spirit, I am concerned here not with the transnational movement or spread of communicative forms but, rather, with the communicative frameworks that mediate the flow of information, ideas, ideologies, languages, and the like. Media technologies are one important and often-studied element of the communicative mediation of transnational flows. As William Mazzarella notes, "Electronic audiovisual media enjoy, as many scholars point out, an overdetermined relationship to the discourse of cultural globalization. They are at once its infrastructural means and its privileged signs" (2004:347-348). Nontechnological elements of communicative frames have received much less attention in discussions of the mediation of transnational relations and global imaginaries. The heightened attention given to communications technologies can make it seem as if such technologies are intrinsic to the communicative mediation of transnational processes and imaginaries.
In this article, I build on the insights of others who have explored the role of nontechnological features of communicative frames in mediating transnational imaginaries. Michel-Rolph Trouillot (2000), for instance, shows how historical apologies mediate a new way of thinking about the nation in the global era: as a liberal subject with a soul capable of feeling guilt that requires expiation. Genre conventions of Orientalist and anthropological texts have themselves been the subject of much scholarly work on frames that mediate Western conceptualizations of transnational relations (e.g., Fabian 1983; Said 1978). However, what communicative frameworks mediate the transnational imaginaries of people operating at a distance from Western political and scholarly institutions? From the "promises of late capitalism" (Comaroff and Comaroff 1999:279) to a transnational distribution of participant roles in which "the center speaks, the periphery listens" (Hannerz 1989:67), anthropologists and others analyze transnational relations in terms of communicative frames, but there has been little ethnographic attention given to the frames that mediate transnational processes and imaginaries for those in the periphery.

In the next section, I discuss the epistemological context of revelatory practice in the Yopno Valley. Knowledge is not something generally understood to be discovered; it circulates through revelations from knowledgeable sources 
to those less knowledgeable. Acts of revelation, then, are moments in a history of knowledge in circulation that in various ways point back to the sources of the knowledge being revealed. This retrospective "glance" of revelation situates acts of revelation as moments in a circulatory history that encompass other persons, places, and times. In later sections, I explain how the revelatory framing of much interaction in the valley now locates Yopno interlocutors within a transnational circulation of knowledge.

\section{ROUTES OF KNOWLEDGE: RE-PRESENTING THE KNOWLEDGE OF THE ANCESTORS}

Ethnographies from throughout New Guinea report a common epistemological theme - the existence of an uncertain reality that lies out of reach of untrained human perception. Dan Jorgensen offers this succinct summary of a Telefol perspective on reality and the way in which people come to understand it: "The key to much of what goes on in the world - both within and beyond the confines of the cult is to be found in awareness, or 'seeing' (utamamin) and a central tenet is that the apparent world conceals a mysterium to be unraveled with the aid of the revelations contained in myth" (Jorgensen 1981:32). In a world populated by spirits, curses, sorcerers, and other unseen powers, the "outward" appearance of things may mask an underlying reality that requires "unraveling" to understand it. However, unlike the inductivist Baconian epistemology, in which nature's secrets are laid bare through scientific experiment and individual reason, knowledge of this underlying reality cannot be gained by an individual through the use of reason and scientific experiment. In this epistemology, new knowledge is not discovered; rather, new sources of knowledge are discovered (Errington and Gewertz 1986). Knowledge is not created by rational individuals; it circulates (or not) through fundamentally unequal social relations. Esoteric knowledge is acquired from those who know more.

Knowledge, from this perspective, always has a history of circulation; it comes from someone, somewhere, at some time. Discussions of esoteric knowledge often explicitly "map" the route through which a representation or admonition has traveled from its source to the here and now of interaction, presenting a provenance that lends it value. Providing sources, though, is a delicate task: sources may strengthen a claim, but they are also open to questioning. A common way to challenge the validity of others' knowledge - for instance, the esoteric clan migration histories and genealogies used to claim landownership - is to challenge the sources of that knowledge.

The following short utterance is one example of how routes of knowledge are "mapped" in discourse. The remark came during a discussion of the local preschool and the problems that had led to the school being shut down. One man had begun recounting a dream he had that would perhaps offer insight into the problems at the school. The dream featured an animal, which I will not identify for reasons that will become clear. While the dream was being recounted, another man in the audience offered up the following bit of esoterica:

\begin{abstract}
My elders said to me: "You should not kill [omitted animal], you all should not kill [omitted animal]. It's something of yours; its spirit is something of yours. [coughing, unhearable] You have to tell your children or your younger brothers that: 'Do not do it, you should not kill any of them." That's what they said to me. [field recording by author, April 15, 2009]
\end{abstract}

The speaker here offers up a piece of esoteric knowledge: the animal featured in the dream is a local spirit of great importance. The village's preschool had been built on a plot of land where this spirit resides. This is the result of a common practice of locating schools and churches where men's houses previously stood, places that are often close to the homes of powerful spirits connected with the men's houses - one of many ways in which former men's houses are linked to present-day churches and schools. Spirits, if not given proper attention, can plague people with sickness and death, and the problems of the preschool were perhaps a sign that things were not right: either the spirit needed to be tended to so as to mollify it or people had been tending to the spirit too much and needed to destroy it using Christian spiritual powers.

Importantly, the speaker locates the esoteric knowledge presented here along a social and temporal trajectory of knowledge in circulation:

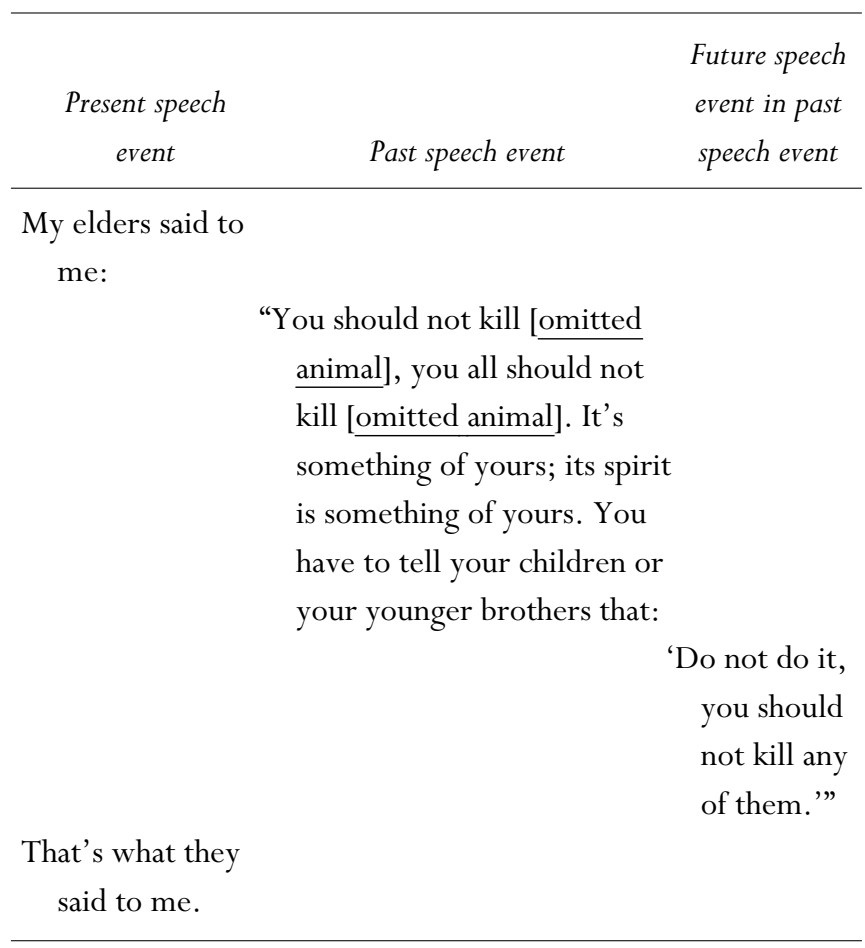

The speaker connects this bit of esoteric knowledge about an animal to its source in a previous speech event in which male elders in his patriline provided knowledge about the nature of this animal and the proper way to treat it, including an 
admonition about to whom to reveal this knowledge ("Past speech event"). In effect, the knowledge introduced by the speaker in the here and now of discourse is located in a history of circulation through social space and time along genealogical and gendered lines from the past ("elders") to the here and now.

Moreover, the lines of transmission outlined in this short speech allude to a broader institutionalized circulation of knowledge associated with the erstwhile men's house (a mode of circulation that does not include the readership of American Anthropologist, and so I exclude the name of the spirit animal from this quoted speech). In the men's house, initiates were instructed in the esoteric knowledge of their ancestors just as their seniors were in a process that was understood to have stretched back to sources of esoterica in the distant past. Thus, the men's house underwrote a presumption of quotation: esoteric speech was presumed to be a re-presentation of the speech of previous generations of men going back ultimately to distant ancestors. The framework of knowledge in circulation institutionalized in the men's house implicitly located esoterica in a history of transmission - a speech chain (Agha 2003) — that followed gendered and genealogical lines. Whether routes of knowledge in circulation are explicitly mapped, as in the example above, or are implicit in the workings of institutions, esoterica is understood to be located in a history of circulation that encompasses other persons, places, and times.

As in many Melanesian polities where the control of knowledge is a source of power (Lindstrom 1984), the ways that knowledge circulates are bound up with relations of power and inequality. This is nowhere more evident than in the circulation of knowledge in the men's house, which delineated one of the major social cleavages in Yopno villages the distinction between initiated men, who controlled powerful knowledge, and women and young children, who did not. In an amusing twist on the connection between knowledge and power institutionalized in Yopno men's houses, people in most villages I visited eagerly told me the "truth" that lay behind the now apparently defunct men's house regime. The men of earlier eras, I was told, would claim that there was a spirit in the men's house, evidenced by its cries for food. The sound of its cries terrified the women and children, and the men would tell them that the spirit was hungry, that they should bring pigs for the spirit to eat. However, in truth, the men now mirthfully point out (often in the company of the women), the cries of the spirit were merely men turning a bullroarer. The pig that was brought for the spirit was in fact destined for the men in the men's house to eat. A common theme in Yopno stories, tricks like this one emphasize the power that comes from having an esoteric understanding of a situation.

The men's houses were dissolved following the arrival of Lutheran missionaries in the 1930s, and people now sense that much of the connection to sources of knowledge and power in the past is lost, a fact they variously applaud and lament. Some ancestral esoterica continues to be passed down, however, though now in more ad hoc ways. Informal men's houses are formed in secret, with young men searching out powerful elders who work with them in seclusion over a series of weeks to pass on their knowledge. Individuals collect genealogies, migration histories, and other esoterica from elders, writing them down in books that they plan to pass on to their children. Some even seek out men's houses among neighboring ethnic groups or on the outskirts of urban areas.

Though the institutionalized circulation of knowledge in the men's house has been disrupted, new sources of knowledge are being put forth by those who claim power and influence. In the next section, I turn to a variety of what might be termed political oratories, in which would-be community leaders frame their efforts to direct the activities of the community as revelations of esoteric knowledge. As I discuss, however, the esoteric knowledge they put forth is not that of patrilineal, male ancestors. It is the knowledge of people outside the community. Their revelations thus point to a very different social, spatial, and temporal framework of knowledge in circulation than that presented in this section.

\section{THE POLITICS OF PERCEPTION AND THE PLAY OF PERSPECTIVES IN POLITICAL ORATORY}

How people perceive reality is a central concern of Yopno politics. People's actions are understood to issue in part from how they see reality, and so to alter their perception of reality is to change the way they act. Politics in Yopno communities, then, often involves efforts to "correct" people's perception of reality in an effort to get them to act correctly or effectively.

Power and influence in this politics of perception is intimately connected to knowledge and its circulation. Providing others with esoteric knowledge - a correct perception of reality - is seen as a way of influencing their actions. Much political oratory is framed as revelation, in which would-be community leaders offer up esoteric perceptions of reality to their "ignorant" addressees under the premise that right thoughts will lead to right actions. I focus here on one rhetorical device in particular that is commonly encountered in revelatory political oratory, what I term the play of perspectives. In the play of perspectives, two perspectives on the same reality are represented: one that is cast as exoteric and the other as esoteric. These are not merely contrasted one with another, but through the presentation of these perspectives, would-be leaders present an esoteric perspective on reality to their exoterically minded addressees.

The play of perspectives makes relatively explicit two key features of the revelatory framework in play in much political oratory. First, it maps the distribution of esoteric knowledge in social space, stating or insinuating who holds 
esoteric and exoteric perceptions of reality. Second, the play of perspectives potentially puts esoteric knowledge into circulation, giving "ignorant" addressees access to the speaker's "esoteric" perspective on reality.

Let us look at an example. The following passage is drawn from a community meeting in the village of Ganggalut. The young man who started this topic of discussion, though still in his thirties, had been elected as the local-level government representative for Ganggalut and the neighboring village of Gua, and he was a strong supporter of the conservation area. He had grown up in a more urban part of Papua New Guinea and attended school through grade 10, which made him one of the more educated people in the Yopno Valley. He projected an image of a man savvy in the ways of government and urban life, an image that made him a viable local-level government candidate despite his youth. Here he is trying to get people to go clean up the site for the upcoming conservation celebration-something most had failed to do the day before.

\author{
Counsellor: Gua, Weskokop, Taeng [the other \\ villages hosting the celebration], they \\ have respect for it [i.e., the conser- \\ vation work]. Ganggalut, we don't \\ have respect for it. \\ Counsellor's brother: We see it as a joke. \\ Counsellor: We see it as a joke, and as a result, \\ they surpass us. They see us as worth- \\ less. [field recording by author, April \\ 13, 2009]
}

The counsellor and his brother introduce a play of perspectives that distinguishes "our" perspective from "theirs," on which the following speakers build. Here is one brief extract taken from another man's comments that continues the play of perspectives introduced by the counsellor and his brother:

\footnotetext{
Our eyes don't see these things [i.e., the benefits of helping with the conservation work]. So we think, "Why will we do this?" While we think that way and are uncertain, other villages have already seen it. They have seen some of the benefits that come from this, so they do the work for this [conservation celebration]. If you do the work, a little later you will see some benefit to you. [field recording by author, April 13, 2009]
}

The play of perspectives in this short extract maps the social distribution of exoteric and esoteric perspectives on work related to the conservation efforts. The speakers distinguish "our" exoteric perspective from "their" esoteric one, indicating that "our" perspective is ignorant in contrast to "their" more experienced and knowledgeable view.

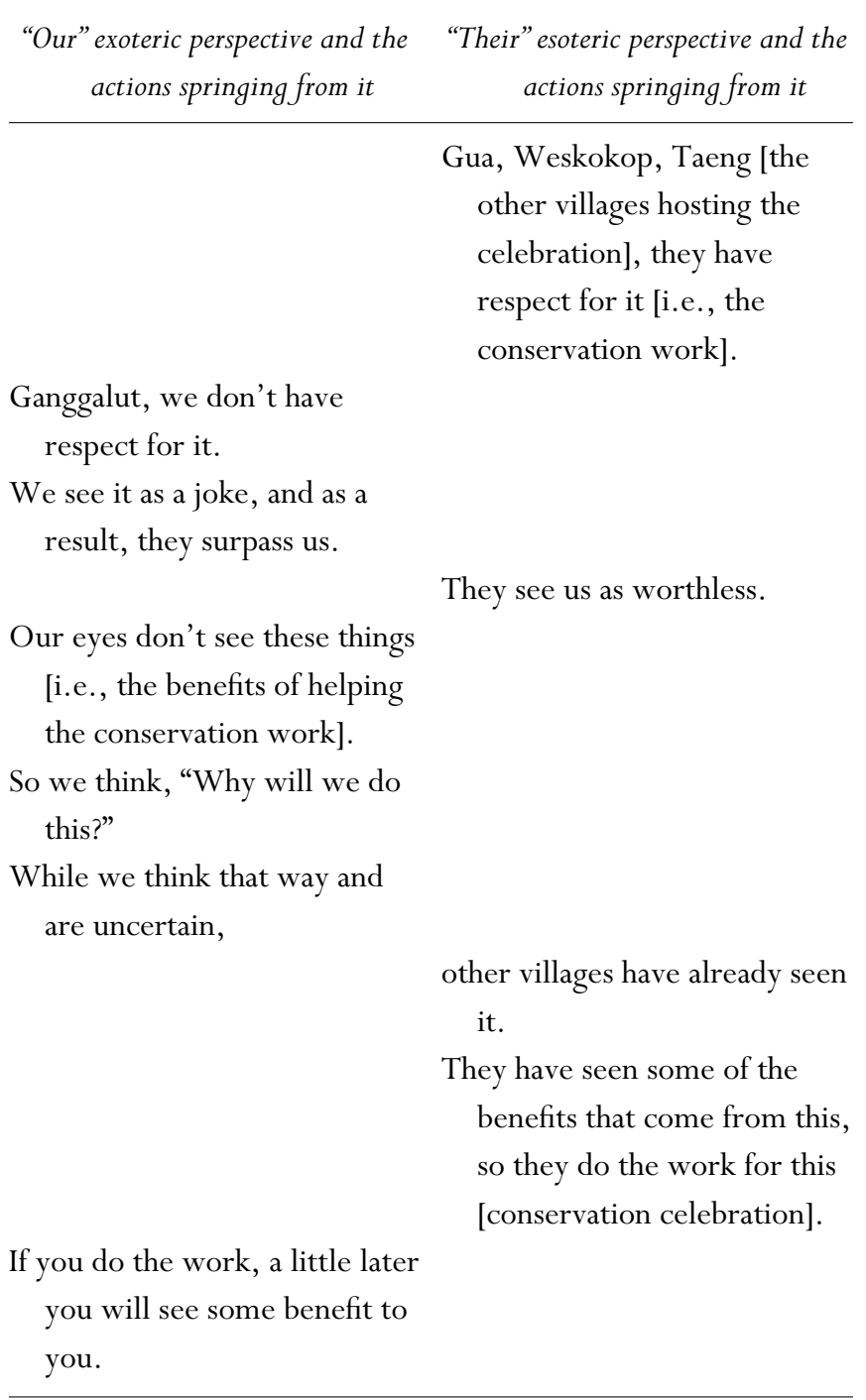

The speakers here map exoteric and esoteric perspectives on the conservation work by village: "us"_-Ganggalut_-as opposed to "them"-Gua, Weskokop, and Taeng. At the same time, though, they insinuate an unequal distribution of knowledge among participants in the interaction. Though the speakers represent themselves as ignorant members of the community (one of "us"), their presentation of others' esoteric perspective suggests otherwise. By re-presenting the perspective of these other neighboring villages, the speakers insinuate that they too see the benefit of helping with the conservation celebration. They may represent themselves as one of "us," ignorant members of the community of Ganggalut, but they align themselves with the perspective of more knowledgeable outsiders.

The speakers not only avoid highlighting the superiority of their own perspective, they avoid directly singling out people who are in need of enlightenment lest it give rise to resentment. People explained to me that they used 
"we" (nin) or the dual "we two" (nit) rather than "you" in situations like this so that no one would think they were being treated as inferior. The effectiveness of the play of perspectives is bound up with inducing shame in those who recognize themselves as holding an "ignorant" view of the situation (cf. LeRoy 1979 on the use of outsiders' perspectives to induce shame and Schieffelin 1986 on the importance of shame and its role in socialization in another region of Papua New Guinea). A sense of shame at being "backward" and "ignorant" provides a stimulus for community members to alter both their perspective and their behavior, but speakers are wary of too baldly pointing out the ignorance of others. Stating too clearly the ignorance of one's addressee and the superiority of one's own perception of reality risks alienating the very people one is trying to influence. Audience members are more often left to recognize resemblances between their own perspective and the ignorant one offered up in the play of perspectives and thereby recognize themselves as addressees in need of the revelation being offered.

In the play of perspectives, would-be leaders map a social distribution of esoteric and exoteric perspectives that includes interactional participants as well as others. Though often not stated baldly, speakers align themselves with an esoteric perspective associated with outsiders while addressees are aligned with a local exoteric perspective, one associated with "here." The play of perspectives in political oratory thus locates the present moment of interaction in a more expansive mapping of the social distribution of knowledge.

Would-be leaders not only map an interactional and social distribution of knowledge through the play of perspectives, they also offer up an esoteric perspective to exoterically minded addressees. In other words, the play of perspectives cues a revelatory interactional framework. In the revelatory framework in play in much political oratory, esoteric perspectives travel along a very different route from the knowledge of ancestral esoterica discussed in the previous section. The knowledgeable perception of reality offered up by people trying to direct community members is most often associated with people outside of the community - a common source of valuable knowledge in Melanesia (e.g., Harrison 2000; Rutherford 2003). It is not "ours" in the way that a clan's or a village's esoterica is considered to be endogenous to it.

In the politics of perception, influence and power are tied to one's position along routes of knowledge in circulation. In their efforts to influence community members, would-be leaders present themselves as mediators who reveal the esoteric perspectives of more knowledgeable outsiders to an "ignorant" and out-of-touch community. Wouldbe leaders lay claim to authority by locating themselves within a social distribution and circulation of knowledge. Of course, community members do not necessarily pay much heed to the "knowledgeable" perspectives that are "revealed" to them. What counts as an esoteric perception of reality is often a matter of dispute. There are multiple, sometimes competing, sources of esoteric perspectives pointed to by people trying to steer community members one way or another. As I show in a later section, others in the valley have very different perspectives on the benefits of doing work related to the conservation efforts from those presented by the counsellor and others in the discussion extracted for this section.

Establishing personal authority goes hand in hand with establishing the authority of the sources of one's knowledge. With the men's houses now largely defunct, several institutions have emerged as particularly authoritative sources of knowledge in the valley, schools and the Lutheran church most prominently. In the next two sections, I look at how the play of perspectives characteristic of much political oratory in community meetings incorporates these "outside" institutions as sources of knowledge affiliated with the transnational sphere.

\section{FROM GOD'S LIPS: HOMILETIC REVELATION AND "OUR" PLACE IN THE GLOBAL CHURCH}

At least once a week, sometimes as frequently as every night, members of Yopno villages gather in Lutheran churches or in the houses of church leaders to sing Christian songs, read the Word of God, and hear a homily, the high point of Yopno church services. The homily almost invariably involves a line-by-line translation of that night's Bible verse(s) from Tok Pisin, the English-based creole used in most people's Bibles, into Yopno. Homilies are generally careful explanations of the day's Bible readings: parables are elucidated by discussing situations more familiar to Yopno life, other Bible passages deemed relevant are discussed, and ultimately the day's text is boiled down to a straightforward maxim that bears on people's daily conduct. In effect, homilies portray God's Word as something difficult and obscure that requires the insight of church-trained pastors and lay leaders to make accessible to "ignorant" parishioner addressees.

Adding to the sense that homilies reveal obscure knowledge is the regular use of the play of perspectives discussed in the previous section. Virtually every homily I heard developed a contrast between a knowledgeable perspective and an ignorant one. The following are selections taken from one homily that elucidates Matthew 14:22-33, the story of Jesus and Peter walking on water. The story, in which Peter walks on water only to sink into the sea, is linked by the homilist to Peter's misplaced belief in his own powers. Having traveled around performing miracles alongside Jesus, Peter begins to think that he himself is the source of his miracle-working power. In the words of the homilist, "Peter went around with thoughts like this: 'It is by means of my power that we are doing this' [i.e., performing miracles]." In a play of perspectives, the homilist contrasts Peter's perspective with Jesus's: "Jesus sees that there is a lack of belief in Peter's thinking. What is he lacking? He is lacking belief." Specifically, Jesus understands that belief in God is the source 
of power, but Peter thinks that he is the source of his own power. According to the homily, Jesus has Peter walk on water to demonstrate to Peter that he is not the source of his power, that without belief in God Peter has no power. After Peter attempts to walk on water only to sink into the sea, the homilist reports Jesus's speech as follows:

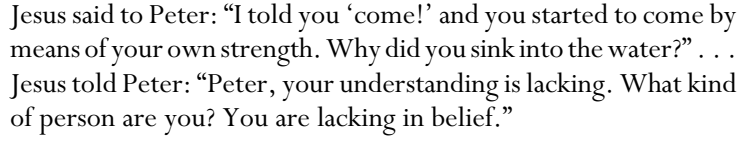
means of your own strength. Why did you sink into the water?" . . Jesus told Peter: "Peter, your understanding is lacking. What kind of person are you? You are lacking in belief."

Peter's misperception of reality is demonstrated, and the truth revealed to him through Jesus's ruse. The homily construes Peter's attempt to walk on water as a revelation in which Jesus reveals an esoteric perspective on power and belief to Peter.

But the story is also presented as a revelation in the here-and-now telling of it, a revelation directed at "us":

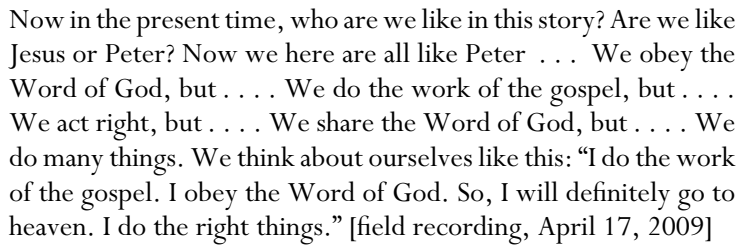

In brief, people today see their actions as the route to salvation. They think that they have the power to save themselves through good works; like Peter, they think that power rests with them. But as the homilist goes on to point out, they, like Peter, lack belief in God, which is the true source of salvation. In the homilist's presentation of this Bible story, Jesus not only reveals to Peter that belief in God is the ultimate source of our capabilities, Jesus also reveals this truth to "us," a revelation mediated by the Bible and the homilist. Much as the ancestors once served as the locus of connection to supermundane powers, Jesus has come to fill that role in church services. Jesus is presented as the source of an enlightened perspective. Indeed, people emphasize the fact that Jesus is often called "teacher" in the Bible. An esoteric understanding of God and His creation is one that "we" ignorant and confused people have access to only through the mediation of Jesus, the Bible, pastors, and other church workers, who bring God's Word to "us."

The juxtaposition of esoteric and exoteric perspectives in homilies conjures a social and temporal trajectory of knowledge in circulation in which God's Word proceeds from the mouth of Jesus through its inscription in the Bible, which was brought by German missionaries to Papua New Guinea, where they trained pastors and church workers in seminaries, who in turn trained lay people like the homilist, giving them the knowledge to pass on to "us" ignorant people in the here-and-now act of homiletic revelation. A matter of frequent discussion inside and outside of Yopno churches, the circulation of God's Word through each of these sites is something of which everyone is aware. Homilies framed as revelations are positioned explicitly and implicitly in a larger institutionalized framework of knowledge in circulation that stretches from God's lips through the Bible and the Lutheran Church to "our" ears.

Homilies and other varieties of Christian discourse, then, map a social distribution of esoteric knowledge that extends from the here and now of interaction to encompass transnational and cosmic realms. They are situated within a transnational imaginary of God's Word circulating from "out there" to "here," positioning missionaries, pastors, church workers, and parishioners along a trajectory of Christian knowledge in circulation. In this transnational communicative imaginary, the Yopno find themselves on the receiving end, though some (e.g., the ignorant parishioner) more than others (e.g., pastors, lay leaders). In a hierarchical vision of the world in which people's places are defined by their position along a trajectory of Christian knowledge in circulation, the Yopno find themselves at the bottom trying to work their way up. As elsewhere in Papua New Guinea, people in the Yopno Valley regard themselves as peripheral to the transnational flow of knowledge and other resources, "the last people" to gain access to Christianity and other goods. This sensibility is cultivated by the revelatory framework in play in much Christian instruction, in which Yopno parishioners are located at the end of a trajectory of knowledge in circulation as the last "ignorant" people in need of enlightenment.

In this section, I have focused on the way in which homilies and other revelatory Christian discourses both construct and are situated within a transnational imaginary of knowledge in circulation. This has brought into relief how the revelatory framework of much Christian discourse positions the Yopno on the periphery of this imaginary, as the last to know. But it should be borne in mind that Yopno pastors and others who reveal God's Word partake in the power that they simultaneously vest in distant authorities. On the one hand, homiletic revelation presents Jesus's words and God's Word as a source of knowledge, as a knowledgeable foreign perspective circulated through the global Lutheran church that "we" should incorporate. On the other hand, homilists present themselves as authoritative sources revealing this foreign knowledge to "ignorant" parishioners. As I have noted before, one's authority and one's position along a trajectory of knowledge in circulation are intimately connected in the politics of perception. To present distant, knowledgeable others as a source of one's knowledge is to claim authority for oneself. In the next section, I look more closely at how transnational imaginaries of knowledge in circulation are bound up in the here and now of revelatory interactions with efforts to attain power and influence in local village politics.

\section{NANDA'S ANSWER: TRANSNATIONAL ESOTERICA IN VILLAGE POLITICS}

The importance of revelation and the attention given to the transnational circulation of God's Word among the Yopno may appear unremarkable. After all, revelation is 
a theme central to Christian texts (Bockmuehl 1990), and the Lutheran Church is composed of a well-developed, transnational network of institutions. But revelation also appears as a central element in Yopno discussions of other projects and institutions, Western-style education and environmental conservation among them. This is striking particularly because revelation is not an element intrinsic to these projects and institutions in the way that it might be considered an element of Christianity propagated through missionization.

The celebration marking the creation of the YUS conservation area brought to the fore people's anxieties about pledging land for conservation, and, as the celebration approached, the U.S.-based conservation NGO became a topic of daily discussion and revelatory insight. One meeting I attended in Weskokop village, though initially focused on the work that needed to be done to prepare for the upcoming celebration, quickly gave way to a discussion of bigger issues. Among the questions people had, many concerned the benefits they would receive in exchange for pledging their land for the conservation area. Among the benefits set up by the conservation NGO was a program to sponsor young people from the Yopno, Uruwa, and Som valleys to attend teacher training college in Lae. Every other year, a number of students from the region would be selected, their schooling would be paid for, and afterward they would be expected to return to the Yopno, Uruwa, and Som valleys to teach in schools for a number of years. However, people were unclear about how these young people were to be selected. Many parents wondered if their children would receive this benefit if they pledged land. Others expected that their help with the upcoming celebration would help earn their children a place in this program. What, they wondered, was the logic of this exchange?

Leading the discussion in Weskokop was Nanda, a middle-aged man who had recently been given charge of the community preschool. As chairman of the preschool board interested in drumming up support for the school, he sought to make clear that it was educational accomplishments that would earn young people a place in the NGO's scholarship program, not land pledges or support for the celebration (see Figure 4).

Nanda:

(1) We will bring firewood. We will get material for torches.

(2) We are going to support this day [i.e., the celebration for the conservation area].

(3) We are going to prepare the village.

(4) There is a reason,

(5) the reward for doing this [e.g., a scholarship to teacher training college].

(6) You do this [i.e., support the celebration] and you educate a person at the same time.

(7) A person [i.e. a conservation worker] will come here and say:
(8) "I see your [child] is prepared. They will go with me [i.e., to teacher training college].”

(9) That's what they will say.

(10) If not, if we haven't educated our [children],

(11) we see the reward come [to others], and we go sit down,

(12) our hopes are dashed.

(13) "Some people have taken the reward for my hard work.

(14) I am devastated."

(15) Will each of us think like that?

Tek:

(16) Previously, I saw our friends in Kewieng village talk like that.

(17) "Before we gave land [to the conservation area],

(18) what land and resources have you [i.e., people selected for scholarships from other villages] yourselves given?"

(19) That's what they said.

(20) After making a huge stink, I bet they used some sorcery or witchcraft.

Nanda:

(21) But they didn't produce any good children.

(22) They [the conservation NGO] saw that the children were not well educated.

(23) "You all are not up to it."

(24) That's what they [the conservation NGO] told them [the people of Kewieng]

(25) and their hopes were dashed. [field recording, March 22, 2009]

Nanda himself was quite wary of the conservation NGO and had refused to pledge land. Despite his opposition, he cites the NGO here as a source of knowledge in his speech. Looking closely, we see that his speech is framed as a revelation, in which he unveils the perspective of the conservation $\mathrm{NGO}$ to his addressees. As in the homily discussed in the previous section, a social and temporal framework of knowledge in circulation is evident in the way ignorant and knowledgeable perspectives are presented in Nanda's speech. This framework emerges through a set of quoted speech events, some having taken place in the past and some potentially taking place in the future. In the past, Kewieng village complained that they had not received any benefit for the land they offered to the conservation area (lines 17-18). In the future, "each of our houses" in Weskokop village will complain about not receiving any benefit for their hard work preparing for the conservation area celebration (lines 13-14). In contrast to these complaints, there is the voice of the conservation NGO in both the past and future making clear that it is education that counts not pledges of land (lines 23 and $8)$. Ultimately, the past and future complaints of the Yopno are revealed to be indicative of their ignorant perspective, which is out of touch with the view of the conservation NGO. 


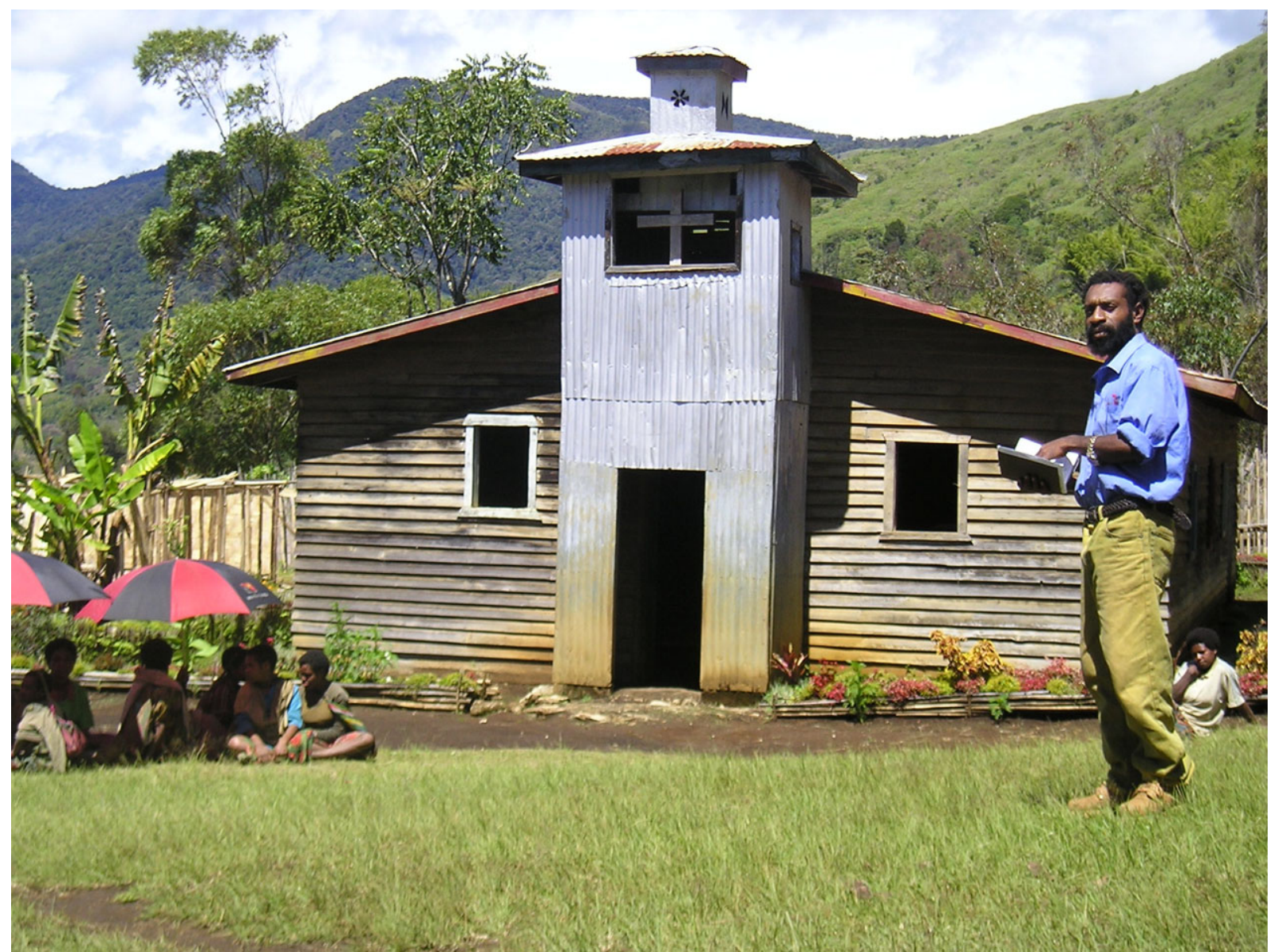

FIGURE 4. A teacher speaks to the students and parents at one of the frequent meetings held in the school area. In the background is a church, which is next to the school in an area that was formerly the site of a men's house.

\section{PAST}

\begin{tabular}{lc}
\hline “Our" exoteric perspective & "Their" esoteric perspective \\
\hline $\begin{array}{l}\text { 16. Previously, I saw our } \\
\text { friends in Kewieng } \\
\text { village talk like that. }\end{array}$ & $\begin{array}{c}\text { 22. They [the conservation } \\
\text { NGO] saw that the } \\
\text { children were not well } \\
\text { educated. }\end{array}$ \\
$\begin{array}{l}\text { 17. "Before we gave land [to } \\
\text { the conservation area], }\end{array}$ & 23. "You all are not up to it." \\
$\begin{array}{l}\text { 18. what land and resources } \\
\text { have you [i.e., people } \\
\text { selected for scholarships } \\
\text { from other villages] } \\
\text { yourselves given?" }\end{array}$ & $\begin{array}{l}\text { 24. That's what they [the } \\
\text { conservation NGO] told }\end{array}$ \\
\end{tabular}

\section{FUTURE}

\begin{tabular}{lc} 
"Our" exoteric perspective & "Their" esoteric perspective \\
\hline $\begin{array}{l}\text { 13. "Some people have } \\
\text { taken the reward for } \\
\text { my hard work }\end{array}$ & $\begin{array}{c}\text { 6. You do this [i.e., } \\
\text { support the celebration] } \\
\text { and you educate a person } \\
\text { at the same time. }\end{array}$ \\
14. I am devastated." & $\begin{array}{l}\text { 7. A person [i.e. a } \\
\text { conservation worker] } \\
\text { will come here and say: }\end{array}$ \\
15. Will each of us think & "I see your [child] is \\
like that? & prepared. They will go \\
with me [i.e., to teacher & training college]."
\end{tabular}


Crucially, these different perspectives map onto the present speech event, the here and now of Nanda's speech. The complaint identified with Kewieng village and "each of our houses" - the complaint of those who pledge land but whose children do not receive scholarships to teacher training college - is a perspective that was immediately recognizable to those in the audience. Many people in Weskokop and other villages had voiced exactly this concern about the benefits they would receive from the conservation NGO. The complaints reportedly made by people in Kewieng village and the complaints "each of our houses" in the future will make (if we do not educate our children) epitomize a widely held "Yopno perspective," one that resonated with the views of Nanda's addressees. Indeed, one young man followed Nanda's turn at talk with a lengthy lament that some of his land was pledged before he properly understood how the benefits were allocated.

Nanda, on the other hand, aligns himself with the speech of the conservation group and its concern for education. Nanda is not only the school board chairman of the Weskokop preschool but also the most educated middleaged man in Weskokop, with a grade 10 education and a limited facility with English. Nanda had represented his community in the Local Level Government Council and was seen as connected to the world of government affairs and urban Papua New Guinea in a way that no other middle-aged person in Weskokop could match.

By aligning himself with the voice of the conservation group, Nanda displays that he, unlike Kewieng and perhaps some in the audience, is "in touch." In contrast, the complaints are made by a typical "out-of-touch" Yopno - that is, one who is not tied in to the circulation of knowledge to which Nanda has access, or rather one who is not tied into that "flow" until the here-and-now moment in which Nanda reveals the reality that the out-of-touch Yopno is not seeing. Nanda presents the here-and-now event of revelation as a historical turning point, asking in effect: Which future do you want? Do we hold onto "our" exoteric perspective and get passed over by the NGO, left with only futile complaints? Or do we take on the esoteric perspective I am now revealing to you, support the preschool, educate our children, and have them selected by the NGO to go to teacher training college?

The here-and-now revelation that it is education, not land, that the conservation NGO is looking for is situated in a larger social and temporal trajectory of knowledge in circulation - circulating from the conservation NGO through Nanda to his addressees now and potentially on through the ranks of the "out-of-touch Yopno" in the future. In the route outlined in Nanda's speech, Nanda as an educated Yopno locates himself in a mediating role in the circulation of knowledge. He positions himself as a local authority, a much-needed source of knowledge for "ignorant" community members.

Moreover, he does not merely inform people that education is what the conservation NGO is looking for, he shows them that education is the route to understanding what people like the conservation NGO want. Later in the meeting, Nanda makes the case for education in a world in which, as he explains to his audience, outsiders (i.e., the IMF and World Bank) are demanding the implementation of taxes and land mobilization (i.e., making land held by customary owners alienable). "How will we find money to pay taxes and defend our land?" he asks. Education is not only the answer to this question, it is what allows Nanda to perceive what the World Bank and IMF intend for the region, a point he drives home by using and explaining English terms like "land mobilization.” Education as a valuable resource, as a route to local power through access to transnational esoterica, is doubly demonstrated here.

Revelations like Nanda's are a regular occurrence in community meetings, constructing a global imaginary populated with the voices and perspectives of national and international actors including the conservation NGO, the Papua New Guinean government, the mass media, the World Bank, urbane Papua New Guineans, and others more in touch with the world "out there." These voices and perspectives do not all concur nor does every audience member accept the "revelations" that Nanda and others offer. Even when "revelations" are rejected, though, it is often on the basis of other "esoteric" perspectives drawn from alternate sources "out there."

The value of esoteric knowledge of the transnationalaccrued and cashed in in acts of revelation like Nanda's drives people to attend schools and churches as sources of knowledge necessary to remain unashamed, to be respected and effective in the world. Though some, like Nanda, oppose the projects of transnational actors and institutions, they still value and desire these actors' knowledgeable perspectives and the esoteric knowledge circulating through these institutions. For many, ancestral knowledge alone is no longer enough. Two Weskokop elders sought out by the conservation NGO for their esoteric knowledge of land boundaries burst into tears after a day out mapping boundaries. Unable to speak back to school-educated, literate NGO workers, they feared that they were giving up their land. Despite their esoteric knowledge of migration histories and land ownership, their lack of Western-style education and savvy about the transnational world made them feel helpless.

Even as the revelatory framework discussed here constructs a global imaginary in which power and valued knowledge are vested in distant actors and institutions, this global imaginary is serving a local, political end - it is used by people like Nanda to position themselves as knowledgeable authorities in their communities. In contrast to the gerontocratic authority legitimized by the circulation of knowledge in the men's house, quite young, school-educated men now offer guidance to their elders, a leadership role that is warranted by their knowledge of the workings of the transnational world. Interactionally, such knowledge and its route of circulation are explicitly and potently 


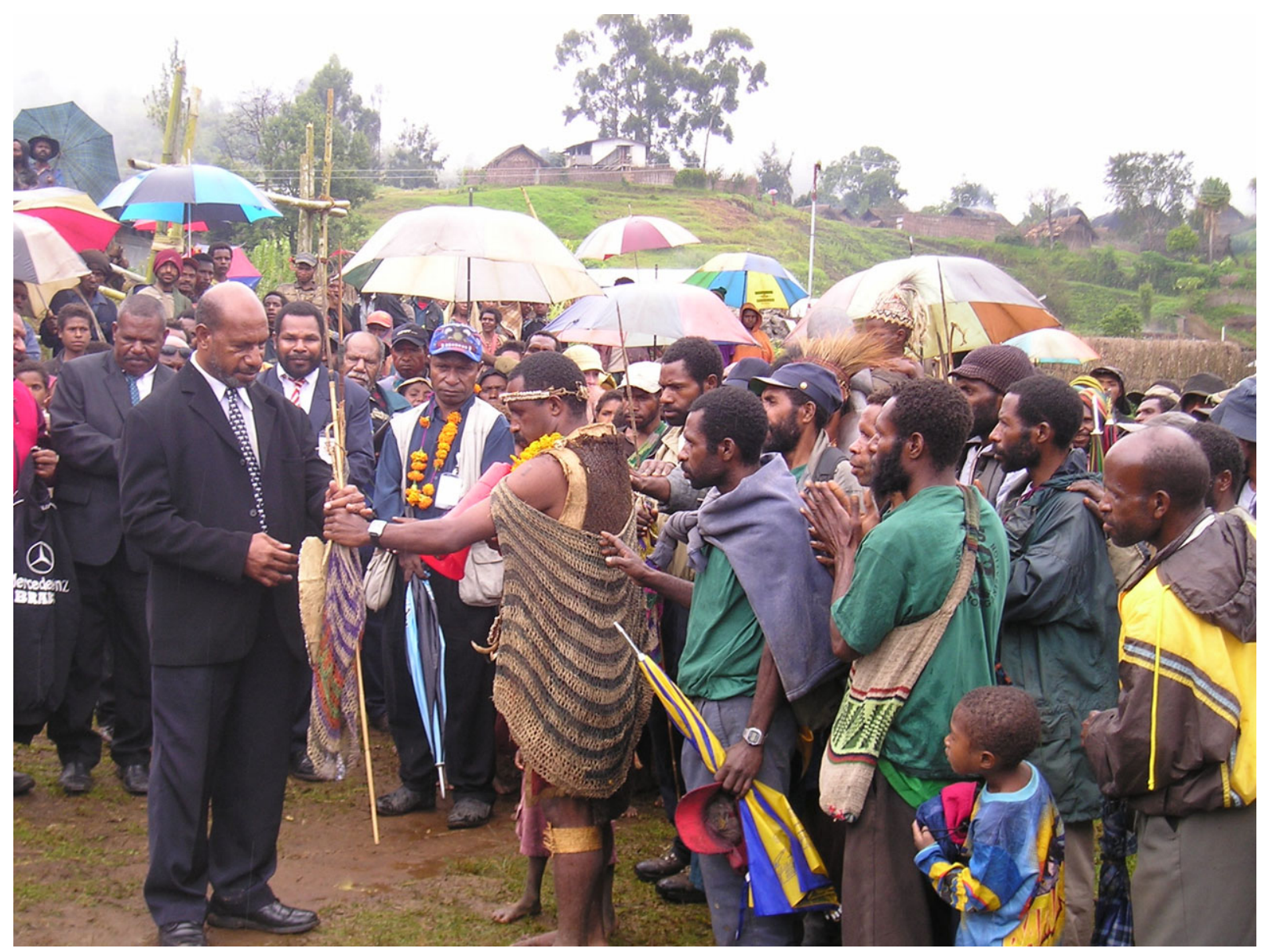

FIGURE 5. An educational leader from the Yopno Valley presents gifts to a member of Parliament at the celebration marking the establishment of the conservation area.

manifested in the play of perspectives, where a knowledgeable "outsider's" perspective (e.g., that of the Christian god or Western NGO workers, the [English-speaking] mass media, or agents of the nation-state) is differentiated from an "ignorant," "backward," or "out-of-touch" Yopno perspective. By situating themselves in a revelatory framework as mediators in the circulation of knowledge from "out there" in the transnational sphere to "here," people like Nanda lay claim to power and influence in their local communities.

\section{CONCLUSION: REVELATORY POLITICS AND THE SENSE OF BEING PERIPHERAL}

For people in this out-of-the-way place, the global appears on a day-to-day basis both in speech and as speech - that is, the global appears in communicative flows of knowledge and social relations with transnational actors take the form of roles in acts of communication (e.g., speakersender, addressee-receiver). More specifically, revelation, as a frame of communicative action, lies at the heart of Yopno engagements with transnational projects ranging from Christian missionization to environmental conservation and development through Western-style education. In revealing the knowledge of transnational actors and institutions to fellow community members, people present them- selves as necessary mediators between an out-of-touch, ignorant local population and an obscure, hidden world of transnational institutions and projects. The global imaginary promoted through this revelatory frame is one in which persons are defined by their place in a global-even cosmic - communicative hierarchy organized by the spatiotemporal trajectory of knowledge in circulation. In this communicative hierarchy, the Yopno are positioned at the bottom, on the receiving end (see Figure 5).

This sense of peripherality is cultivated in part by the revelatory frame through which the politics of perception operates in Yopno communities. Shame and humiliation at being "ignorant," "backward," and "out of touch" are the stock in trade of village politics, not only the result of humiliations visited on people in the Yopno Valley by outsiders in the colonial and postcolonial eras. Village politics and transnational imaginaries are interwoven. On the one hand, local politicking in Yopno villages is global and has been, it seems, since the colonial era. People vie for influence, and inequalities are legitimized with reference to transnational distributions and flows of knowledge. On the other hand, "the global" is in part a product of village politics. Transnational imaginaries are constituted and reinforced in the revelatory politics that plays out in day-to-day 
community meetings and church services in which people seek to influence their fellow villagers.

In a another region of Papua New Guinea, Joel Robbins (1998) has described how Sunday morning church services serve as a frame through which Urapmin take part in a kind of communion with other Christians around the world who are "simultaneously" praying to the same God and hearing the same gospel. People aspire to be full participants in this transnational community, and this transnational communion experienced on Sunday mornings motivates them to work at becoming good Christians. As we have seen in the Yopno material discussed here as well, people not only imagine "the global," they interact with it and participate in it. Importantly, they do so through a variety of different interactional frames: prayer, apology, advocacy, giving voice, revelation, and so on. Each of these terms only vaguely hints at the complex interactional frames prominent in different institutions and speech communities, but they point to the wide array of modes in which people may construct and participate in "the global" in the here and now of interaction.

The frames through which people imagine and interact with each other in a "global" context in turn influence how transnational processes play out in different places: the Urapmin go to church; the Yopno go to school. These imaginaries are not idle fantasies that have no effect on the "real" transnational forces at work. Given the role of revelation in mediating both local politics and the global imaginary in Yopno communities, it is not surprising that the postcolonial era has seen an efflorescence of communication-centered institutions in the Yopno Valley. While cash crops like coffee go largely ignored, it is churches and schools that lie at the center of Yopno attention. These institutions provide access to valued "global" knowledge, a source of power in local politicking and beyond. It is not only the information "flowing" through schools and churches but crucially the revelatory mediation of these flows that is reshaping Yopno life at present. The revelatory mediation of transnational flows is the site where sociopolitical relations in Yopno communities are being reconfigured and where a transnational imaginary is being shaped, and it is where the purpose and value of relatively new institutions - especially churches and schools - are being defined. It is here, too, that people are striving to become less peripheral, to escape shame, and to build a future around the knowledge of others.

James Slotta Department of Anthropology, University of California, San Diego, La Jolla, CA 92093; jslotta@ucsd.edu

\section{NOTES}

Acknowledgments. First and foremost, I am deeply grateful to the many people in the Yopno Valley who supported this research in one way or another. I must particularly single out for thanks Korus, Damlap, Bayanggen, Drongo, and Koki, who assisted with transcribing, translating, and interpreting the speech events excerpted here.
My research would not have been possible without the generous financial support provided by a Fulbright-Hayes DDRA Fellowship and a Wenner-Gren Dissertation Fieldwork Grant. I thank Lise Dobrin for the chance to present an earlier draft of this article at the Linguistic Anthropology Seminar at the University of Virginia. Audiences there and at Franklin and Marshall College provided much valuable feedback. Luke Fleming and Courtney Handman read more drafts than anyone should have to. Finally, I am deeply grateful to Michael Chibnik and several anonymous reviewers for their painstaking comments, which improved the final product substantially.

1. I am translating two Yopno terms, aynoman a- and aysiysiy a-, as revelation here. Both are causative constructions: the first more closely meaning "to make something visible/evident" and the second "to make light shine on something, to illuminate something, to make something clear." Because they are causative, they imply that the object that is "made evident" was in a state of invisibility or concealment prior to its "illumination." The English term revelation captures the contrast of "hidden" and "evident," which is an important part of the meaning of the Yopno terms. This contrast is central to the discussion of revelation, confession, and other similar genres throughout New Guinea (Kulick 1998; Robbins 2001; Rumsey 2008; Schieffelin 2008; Strathern 1979; Weiner 1983).

2. The use of the terms global and transnational here not only reflects recent anthropological interest in transnational processes and institutions; it is also an effort to characterize one way in which people in the Yopno Valley conceptualize their social world. Given a widely shared, largely negative view of their nation (a view found throughout Papua New Guinea; cf. Robbins 1998), many Yopno make considerable effort to connect themselves to actors and institutions in "more developed" nations. Connections to foreign NGOs, churches, schools, and the like can lend them supranational prestige. My use of the term transnational, then, is an attempt to articulate current anthropological concerns with a perspective on the nation and transnational relations of importance to people in the Yopno Valley.

3. Jakobson (1990) provides a foundational discussion of the role of shifters as the quintessential linguistic elements that relate events represented in speech to the speech event itself. In this article, I focus in particular on pronouns and tense as shifters occurring with verbs of speaking, cognition, and perception. These shifters locate revelatory speech events and their participants relative to the perspectives of others at other times. For the reader interested in looking more closely at the role of these linguistic elements in Yopno revelations, transcripts with interlinear glosses are available in the supporting information available online via the Wiley-Blackwell American Anthropologist site.

4. The contrast of knowledgeable and ignorant perspectives is a rhetorical feature of discourse in other areas of Papua New Guinea as well. Schieffelin has documented a similar play of perspectives in a Bosavi health lesson (1995:234), wherein the mediating role of a "book" (a booklet about malaria) as a source of knowledge is indicated through the use of a newly innovated evidential marker glossed as "'we now know from this source, we did not know before' (used when referring to information from written 
sources)" (1995:230). This evidential marker neatly captures the play of perspectives that in Yopno generally involves the use of verbs of speaking, cognition, and perception, as Yopno does not have evidential markers. Schieffelin highlights the newness in Bosavi of both the evidential marker and the interactional framework in which it occurs. Among the Yopno, the play of perspectives and the revelatory interactional frame appear in a wide variety of different social contexts. They do not appear to be a recent historical innovation, but this cannot be determined definitively.

\section{REFERENCES CITED}

Agha, Asif

2003 The Social Life of Cultural Value. Language and Communication 23:231-273.

Anderson, Benedict

1991 Imagined Communities: Reflections on the Origin and Spread of Nationalism. London: Verso.

Bakhtin, M. M.

1981 Discourse in the Novel. In The Dialogic Imagination: Four Essays. Michael Holquist, ed.; Caryl Emerson and Michael Holquist, trans. Pp. 259-422. Austin: University of Texas Press.

Bockmuehl, Markus N. A.

1990 Revelation and Mystery in Ancient Judaism and Pauline Christianity. Tubingen: J. C. B. Mohr.

Comaroff, Jean, and John L. Comaroff

1999 Occult Economies and the Violence of Abstraction: Notes from the South African Postcolony. American Ethnologist 26(2):279-303.

Errington, Frederick, and Deborah Gewertz

1986 The Confluence of Powers: Entropy and Importation among the Chambri. Oceania 57(2):99-113.

Fabian, Johannes

1983 Time and the Other: How Anthropology Makes Its Object. New York: Columbia University Press.

Gal, Susan

2003 Movements of Feminism: The Circulation of Discourses about Women. In Recognition Struggles and Social Movements: Contested Identities, Agency and Power. Barbara Hobson, ed. Pp. 93-118. Cambridge: Cambridge University Press.

Goffman, Erving

1974 Frame Analysis: An Essay on the Organization of Experience. New York: Harper and Row.

1979 Footing. Semiotica 25(1-2):1-30.

Hannerz, Ulf

1989 Notes on the Global Ecumene. Public Culture 1(2):66-75.

Harrison, Simon

2000 From Prestige Goods to Legacies: Property and the Objectification of Culture in Melanesia. Comparative Studies in Society and History 42(3):662-679.

Inda, Jonathan Xavier, and Renato Rosaldo

2008 Tracking Global Flows. In The Anthropology of Globalization: A Reader. Jonathan Xavier Inda and Renato Rosaldo, eds. Pp. 3-46. Oxford: Blackwell.
Jakobson, Roman

1990 Shifters and Verbal Categories. In On Language. Linda R.

Waugh and Monique Monville-Burston, eds. Pp. 386-392.

Cambridge: Harvard University Press.

Jorgensen, Dan

1981 Taro and Arrows: Order, Entropy, and Religion among the Telefolmin. Ph.D. dissertation, Department of Anthropology and Sociology, University of British Columbia.

Keane, Webb

2007 Christian Moderns: Freedom and Fetish in the Mission Encounter. The Anthropology of Christianity series. Berkeley: University of California Press.

Kulick, Don

1992 Language Shift and Cultural Reproduction: Socialization, Self, and Syncretism in a Papua New Guinean Village. Studies in the Social and Cultural Foundations of Language. Cambridge: Cambridge University Press.

1998 Anger, Gender, Language Shift, and the Politics of Revelation in a Papua New Guinea Village. In Language Ideologies: Practice and Theory. Bambi B. Schieffelin, Kathryn A. Woolard, and Paul V. Kroskrity, eds. Pp. 87-102. Oxford Studies in Anthropological Linguistics series. Oxford: Oxford University Press.

LeRoy, John D.

1979 The Ceremonial Pig Kill of the South Kewa. Oceania 49(3): 179-209.

Lindstrom, Lamont

1984 Doctor, Lawyer, Wise Man, Priest: Big-Men and Knowledge in Melanesia. Man (N.S.) 19(2):291-309.

Mazzarella, William

2004 Culture, Globalization, Mediation. Annual Review of Anthropology 33:345-367.

Robbins, Joel

1998 On Reading "World News": Apocalyptic Narrative, Negative Nationalism and Transnational Christianity in a Papua New Guinea Society. Social Analysis 42(2):103-130.

2001 God Is Nothing But Talk: Modernity, Language, and Prayer in a Papua New Guinea Society. American Anthropologist 103(4):901-912.

Rumsey, Alan

2008 Confession, Anger and Cross-Cultural Articulation in Papua New Guinea. Anthropological Quarterly 81(2):455-472.

Rutherford, Danilyn

2003 Raiding the Land of the Foreigners: The Limits of the Nation on an Indonesian Frontier. Princeton: Princeton University Press.

Said, Edward W

1978 Orientalism. New York: Pantheon.

Schieffelin, Bambi B.

1986 Teasing and Shaming in Kaluli Children's Interactions. In Language Socialization across Cultures. Bambi B. Schieffelin and Elinor Ochs, eds. Pp. 165-181. Studies in the Social and Cultural Foundations of Language, 3. Cambridge: Cambridge University Press.

1995 Creating Evidence: Making Sense of Written Words in Bosavi. Pragmatics 5(2):225-243. 


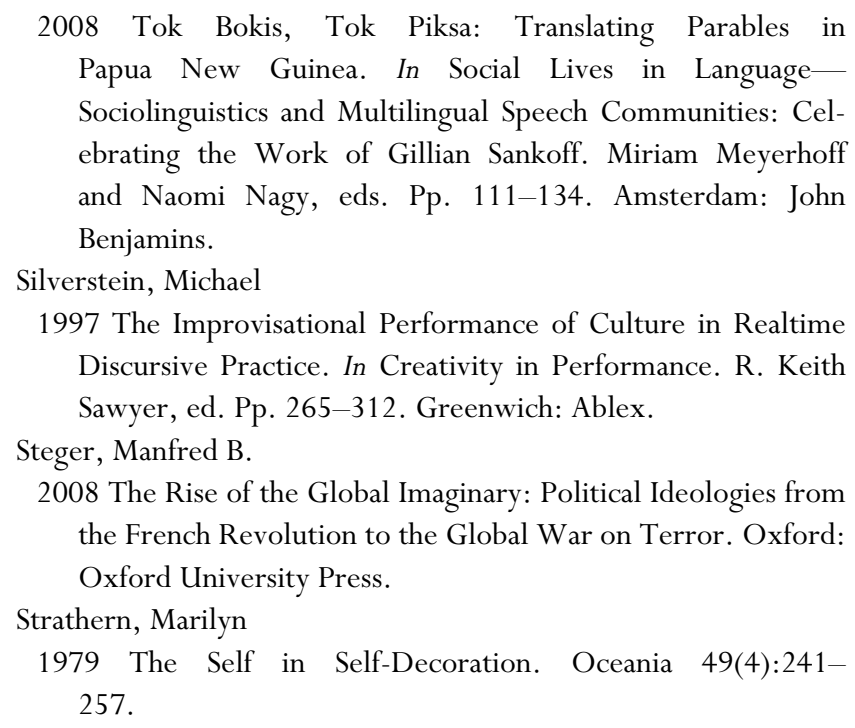

\section{Supporting Information}

Additional supporting information may be found in the online version of this article at the publisher's website:
Taylor, Charles 2004 Modern Social Imaginaries. Durham: Duke University Press. Trouillot, Michel-Rolph 2000 Abortive Rituals: Historical Apologies in the Global Era. Special issue, "Righting Wrongs, Re-writing History," Interventions: International Journal of Postcolonial Studies 2(2):171186.

Tsing, Anna

2000 The Global Situation. Cultural Anthropology 15(3):327360.

Warner, Michael

1990 The Letters of the Republic: Publication and the Public Sphere in Eighteenth-Century America. Cambridge: Harvard University Press.

Weiner, Annette B.

1983 From Words to Objects to Magic: Hard Words and the Boundaries of Social Interaction. Man (N.S.) 18(4):690-709.

\section{Transcripts}

